\title{
The diversity of zerconid mites (Acari, Zerconidae) in Giresun province, with a new record for the Turkish fauna
}

\author{
M. KARACA ${ }^{1 *} \&$ R. URHAN ${ }^{2}$ \\ ${ }^{1}$ Mehmet Karaca, Pamukkale University, Institute of Sciences, Systematic Zoology Laboratory, Kınıkl \\ Campus, 20070,Denizli,Turkey,E-mail: m.karaca_86@hotmail.com \\ ${ }^{2}$ Raşit Urhan, Pamukkale University, Faculty of Arts and Sciences, Biology Department, Kınıklı Campus, \\ 20070, Denizli, Turkey, E-mail: rurhan@pau.edu.tr.*corresponding author
}

\begin{abstract}
The zerconid mites collected from the Giresun province between December 2009 - April 2011 are evaluated and the following species are recorded: Prozercon buraki, $P$. demirsoyi, $P$. giresunensis, $P$. mersinensis, $P$. murati, $P$. satapliae, P. traegardhi, P. turcicus, Zercon adoxyphes, Z. agnostus, Z. berlesei, Z. bulancakensis, Z. bulgaricus, Z. colligans, $Z$. denizliensis, Z. imperfectsetosus, Z. karadaghiensis, Z. mirabilis and Z. ozkani. Of these, Z. karadaghiensis is recorded for the first time from Turkey. Description and drawings of the newly recorded species are given. On the basis of the collected specimens, measurements of nineteen species are given and their geographic distributions are discussed. Additionally, altitude and habitat preferences of the zerconid species are presented with 3 figures and 4 tables.
\end{abstract}

Keywords. Acari, Zerconidae, new record, Zercon karadaghiensis, Giresun, Turkey

\section{INTRODUCTION}

A ccording to recent molecular systematic studies, the family Zerconidae belongs to the suborder Monogynaspida, cohort Gamasina and the superfamily Zerconoidea (Sikora 2014).

Zerconid mites are important members of the soil fauna and these free-living mites colonize various soil substrates (Karaca \& Urhan 2015a). They are mostly associated with humus, decomposed litter, leaf mold, decaying plant materials, and mosses (Urhan 2010), however, there are rare records from woody substrates, ant-hills, nests of birds and small terrestrial mammals (Mašán \& Fend'a 2004) as well. These small, predatory mites feed on the eggs, larvae, and nymphs of other mites and springtails (Shereef et al. 1984, Martikainen \& Huhta 1990). Their wide range of habitats and diverse functional traits make the zerconid mites suitable as bioindicators of environmental changes (Sikora 2014).

The average body length of a zerconid mite can vary between 200-700 micrometers. Their dorsal shields are divided into two separate parts: podonotum and opisthonotum. These mites are weakly sclerotized and their life cycle includes four active stages; larva, protonymph, deutonymph and adult. The most important characters distinguishing zerconid mite species are the number of setae situated on the peritremal shield, the shape and length of peritremal setae, the shape of the posterior part of the peritremal shield and its connection with the ventrianal shield, the shape of the slit between the lateral margin of the peritremal shield and the podonotal shield, condition of the adgenital shields and gland openings gv2, the number of setae of the ventrianal shield, the condition of the dorsal cavities, the number of setae in the marginal setal series of the opisthonotum, the setal pattern of opisthonotal setae and the shape of epistome (Sikora 2014).

The members of the family Zerconidae are well known from the Holarctic region (Krantz 1978), however, in recent years there have been reports from the alpine zone of Central Mexico and Thailand (Ma et al. 2011, Ujvári 2011a, b, 2012) as well. At present, approximately 40

urn:lsid:zoobank.org:pub:B7276EF0-D140-4346-8199-C6798BC49E13

HU ISSN 2063-1588 (online), HU ISSN 0237-5419 (print) http://dx.doi.org/10.18348/opzool.2015.2.199

*A summary of Zercon karadaghiensis was presented as a poster and published as an abstract at $21^{\text {st }}$ National Biology Congress, which was held at Ege University, between 3-7 September 2012, in İzmir, Turkey. 
genera consisting of some 400 species are known worldwide. From Turkey, until now only two genera, Prozercon and Zercon, and 88 species were recorded (Karaca \& Urhan 2014, 2015b).

The first study on Turkish zerconids was published by a Polish acarolog, C. Błaszak (1979) based on samples collected by B. Dominiak and J. Pawlowski in the Amanos Mountains and the surrounding Bolu province. From 1992 to date, further studies on zerconids were published by $\mathrm{R}$. Urhan and his team.

As a contribution to the knowledge of Zerconidae and understanding of the mite faunal richness of Turkey, here we report on nineteen zerconid species belonging to two genera (Prozercon and Zercon) from the Giresun province. Their localities in Giresun and known distributions in the world are given. Furthermore, detailed description and drawings of the newly recorded Zercon karadaghiensis are presented. Altitude and habitat preferences of the zerconid species collected are also discussed.

\section{MATERIAL AND METHODS}

Soil and litter samples were taken from 309 different localities in forestlands of Giresun province. Giresun province is located in the Eastern Black Sea Region of Turkey (Fig. 1). It is surrounded with the Black Sea coasts from the north and the range of North Anatolian Mountains from south. Although the Kelkit valley is covered with steppes, the area between coast and mountains is covered with forests. Total land area of the province is 6934 square kilometers.

The samples collected were placed in plastic bags, labelled and transferred to the laboratory and placed in combined Berlese funnels. Mites were extracted for 5-7 days according to the humidity of the samples. At the end of this process, the contents of the bottles were transferred to Petri dishes and the mites were separated under a stereo-microscope. They were placed in $60 \%$ lactic acid for clearing and mounted on permanent microscope slides using a glycerine medium. The examination and drawing of mites were carried out using an Olympus BX50 microscope with
DP25 camera. The examined materials are stored in $70 \%$ ethanol and deposited in the Acarology Laboratory of Pamukkale University, Denizli (Turkey). Morphological terminology, idiosomal chaetotaxy and poidotaxy (Fig. 2) used in the description follows that of Mašán \& Fend'a (2004). All measurements are given in micrometers $(\mu \mathrm{m})$.

\section{RESULTS}

\section{Family Zerconidae Canestrini, 1891}

\section{Genus Prozercon Sellnick, 1943}

Type species. Zercon fimbriatus C. L. Koch, 1839

Prozercon buraki Urhan, 2008

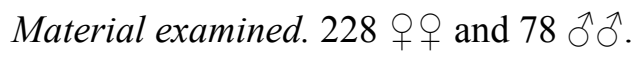

Average length and width of idiosoma: $300 / 238 \mu \mathrm{m}$ (in females); $245 / 202 \mu \mathrm{m}$ (in males).

Localities in Giresun. Centre, Bulancak, Piraziz, Eynesil and Yağlidere.

Known distribution. Turkey (Urhan 2008).

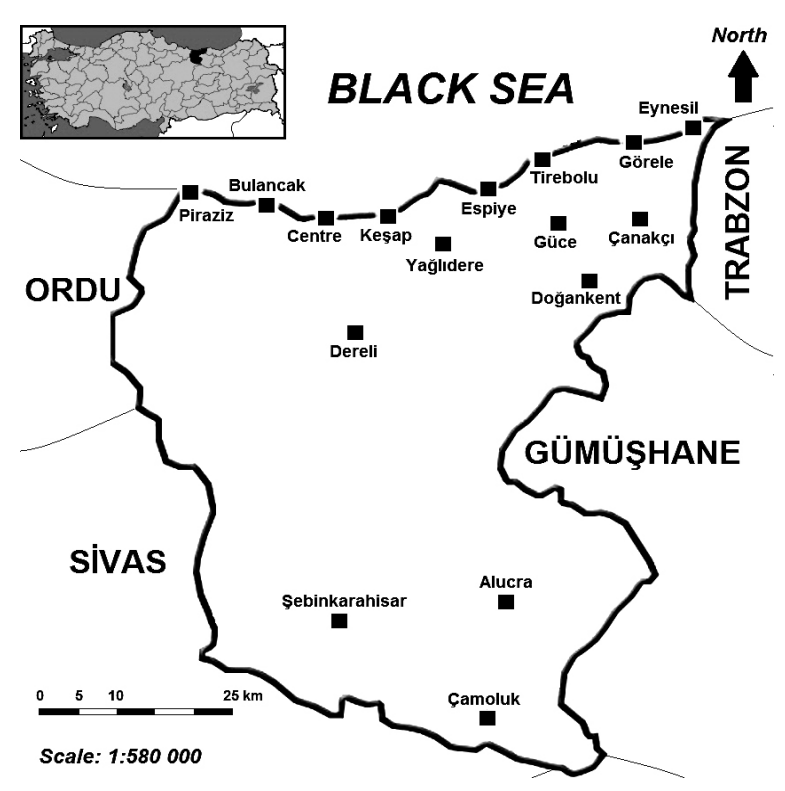

Figure 1. Location of Giresun province and its districts. 


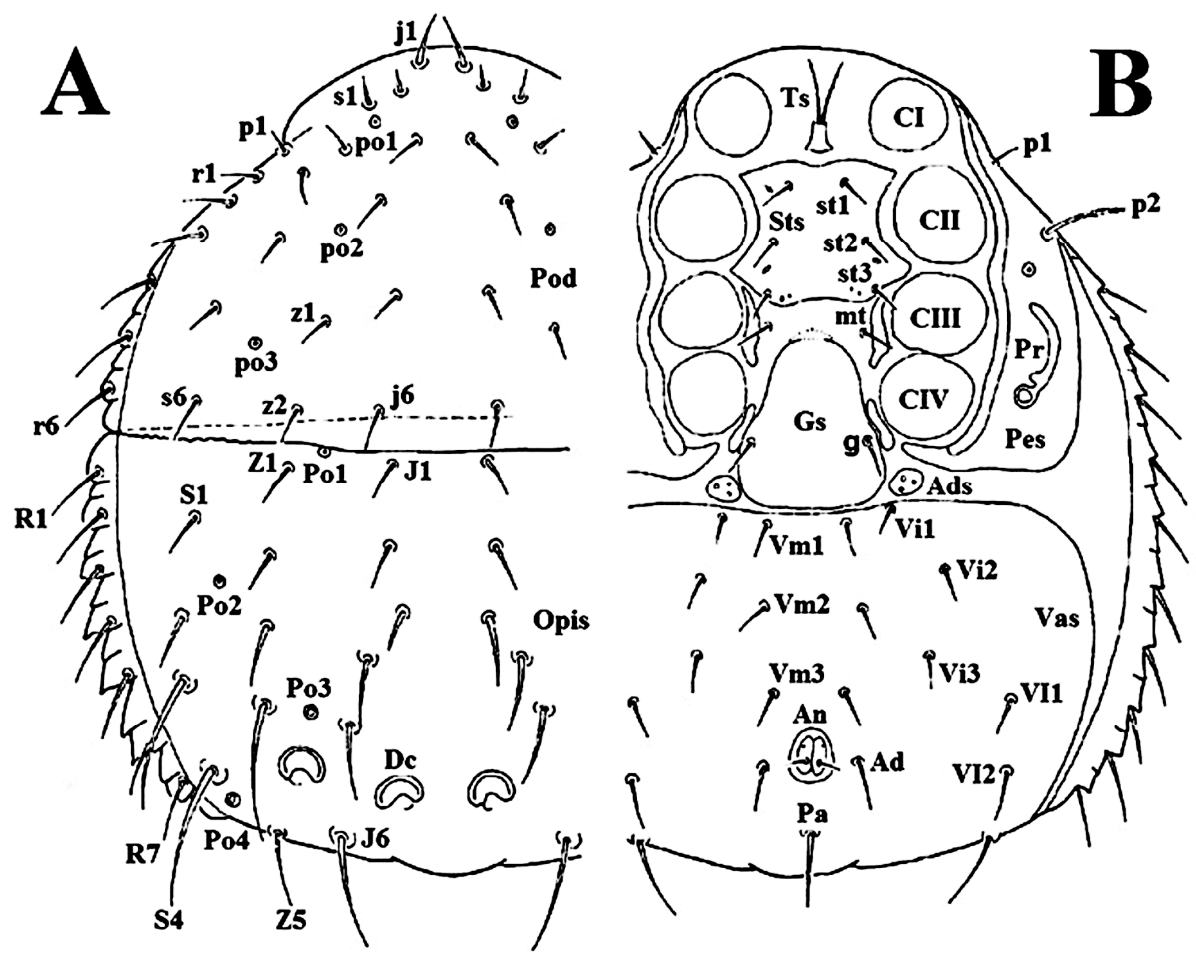

Figure 2. General view of a zerconid mite (female): A) dorsal view, B) ventral view. Abbreviations: (Pod) podonotum, (j1-6, z12, s1-6, p1-2 and r1-7) podonotal setae, (po1-3) podonotal glands, (Opis) opisthonotum, (J1-6, Z1-5, S1-4 and R1-7) opisthonotal setae, (Po1-4) opisthonotal glands, (Dc) dorsal cavities, (Ts) tritosternum, (Sts) sternal shield, (st1-st3) sternal setae, (mt) metasternal seta, (Gs) genital shield, (g) genital seta, (CI-CIV) endopodal shields, (Ads) adgenital shield, (Pr) peritreme, (Pes) peritremal shield, (Vas) ventroanal shield,(Vm1-Vm3) ventromediales setae, (Vi1-Vi3) ventrointernales setae, (VI1-VI2) ventrolaterales setae,(An) anal orifice, (Ad) adanal setae, (Pa) postanal seta (modified after Masan \& Fend'a, 2004).

\section{Prozercon demirsoyi Urhan \& Ayyıldız, 1996}

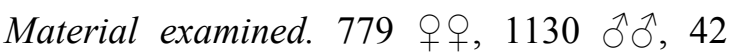
deutonymphs and 6 protonymphs.

Average length and width of idiosoma: $344 / 283 \mu \mathrm{m}$ (in females); $289 / 197 \mu \mathrm{m}$ (in males).

Localities in Giresun. All counties (except Espiye, Şebinkarahisar, Alucra and Çamoluk).

Known distribution. Turkey (Urhan \& Ayy1diz 1996d).

\section{Prozercon giresunensis Urhan, 2013}

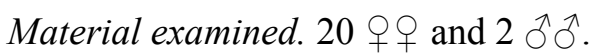

Average length and width of idiosoma: $343 / 242 \mu \mathrm{m}$ (in females); 286/195 $\mu \mathrm{m}$ (in males).

Localities in Giresun. Şebinkarahisar and Doğankent.

Known distribution. Turkey (Urhan 2013).

Remark. Type materials of this species were collected from Giresun province.

\section{Prozercon mersinensis Urhan, 1998}

Material examined. 101 우 우 and $35 \hat{\jmath} \widehat{\partial}$.

Average length and width of idiosoma: $350 / 252 \mu \mathrm{m}$ (in females); $289 / 225 \mu \mathrm{m}$ (in males). 
Recorded localities in Giresun. Şebinkarahisar and Doğankent.

Known distribution. Turkey (Urhan 1998).

\section{Prozercon murati Urhan, 2013}

Material examined. 12 우우 and $2 \widehat{0} \widehat{\partial}$.

Average length and width of idiosoma: $308 / 226 \mu \mathrm{m}$ (in females); $255 / 185 \mu \mathrm{m}$ (in males).

Localities in Giresun. Tirebolu.

Known distribution. Turkey (Urhan 2013).

Remark. Type materials of this species were collected from Giresun province.

\section{Prozercon satapliae Petrova, 1977}

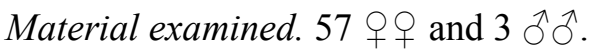

Average length and width of idiosoma: $344 / 265 \mu \mathrm{m}$ (in females); $285 / 214 \mu \mathrm{m}$ (in males).

Localities in Giresun. Espiye, Eynesil and Doğankent.

Known distribution. Russia and Turkey (Urhan \& Ayyıldiz, 1996e).

\section{Prozercon traegardhi (Halbert, 1923)}

Material examined. 188 오, 62 ठิळ and 19 deutonymphs.

Average length and width of idiosoma: $337 / 242 \mu \mathrm{m}$ (in females); $272 / 184 \mu \mathrm{m}$ (in males).

Localities in Giresun. All counties (except Tirebolu, Şebinkarahisar and Çamoluk).

Known distribution. Cosmopolitan in the Holarctic region (Urhan \& Ayyıldız 1992, Karaca 2015).

\section{Prozercon turcicus Urhan \& Ayyıldı, 1996}

Material examined. 111 우 and 41 ภे $\widehat{\partial}$.

Average length and width of idiosoma: $331 / 265 \mu \mathrm{m}$ (in females); $275 / 207 \mu \mathrm{m}$ (in males). kent.

Localities in Giresun. Bulancak and Doğan-

Known distribution. Turkey (Urhan \& Ayy1diz 1996a).

\section{Genus Zercon C. L. Koch, 1836}

Type species. Zercon triangularis C. L. Koch, 1836

\section{Zercon adoxyphes Blaszak, 1979}

Material examined. 13 ठैगे and 40 deutonymphs.

Average length and width of idiosoma: $-/-\mu \mathrm{m}$ (in females); 432/347 $\mu \mathrm{m}$ (in males).

Localities in Giresun. Doğankent.

Known distribution. Iran and Turkey (Urhan \& Ayyıldız 1994b).

\section{Zercon agnostus Blaszak, 1979}

Material examined. 44 우, 85 ภे $\hat{\sigma}$ and 66 deutonymphs.

Average length and width of idiosoma: $496 / 363 \mu \mathrm{m}$ (in females); $391 / 284 \mu \mathrm{m}$ (in males).

Localities in Giresun. Alucra.

Known distribution. Turkey (Urhan et al. 2007).

\section{Zercon berlesei Sellnick, 1958}

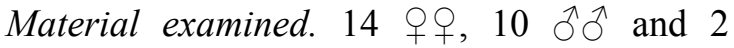
deutonymphs.

Average length and width of idiosoma: $505 / 365 \mu \mathrm{m}$ (in females); $396 / 271 \mu \mathrm{m}$ (in males).

Localities in Giresun. Yağlıdere, Doğankent.

Known distribution. Iceland, British Isles, Poland, Czech Republic, Slovakia, Hungary, Romania, Italy, Spain and Turkey (Urhan \& Ayyıldız 1996c, Mašán \& Fend'a 2004).

\section{Zercon bulancakensis Urhan, 2012}

Material examined. 579 우, 126 ภิ ภิ, 34 deutonymphs and 12 protonymphs.

Average length and width of idiosoma: $427 / 339 \mu \mathrm{m}$ (in females); $338 / 255 \mu \mathrm{m}$ (in males).

Localities in Giresun. Bulancak, Espiye, Görele, Şebinkarahisar and Doğankent. 
Known distribution. Turkey (Urhan 2012).

Remark. Type materials of this species were collected from Giresun province.

\section{Zercon bulgaricus Balogh, 1961}

Material examined. 7 우, $5 \widehat{\partial} \widehat{O}$ and 2 deutonymphs.

Average length and width of idiosoma: $448 / 311 \mu \mathrm{m}$ (in females); $356 / 240 \mu \mathrm{m}$ (in males).

Localities in Giresun. Doğankent.

Known distribution. Albania, Bulgaria, Crimea and Turkey (Urhan \& Ayy1ldız 1996b, Ujvári 2010).

\section{Zercon colligans Berlese, 1920}

Material examined. 396 우, 539 ธิธิ, 229 deutonymphs and 44 protonymphs.

Average length and width of idiosoma: $428 / 320 \mu \mathrm{m}$ (in females); 337/232 $\mu \mathrm{m}$ (in males).

Localities in Giresun. Eynesil, Alucra and Çamoluk.

Known distribution. Cosmopolitan in the Holarctic region (Sellnick 1958, Urhan \& Ayyıldız 1994b, Karaca 2015) .

\section{Zercon denizliensis Urhan, 2011}

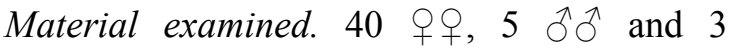
deutonymphs.

Average length and width of idiosoma: $440 / 367 \mu \mathrm{m}$ (in females); 337/263 $\mu \mathrm{m}$ (in males).

Localities in Giresun. Centre and Piraziz.

Known distribution. Turkey (Urhan, 2011).

\section{Zercon imperfectsetosus Urhan, 2012}

Material examined. 68 우, 40 ते $\sigma^{\lambda}$ and 7 deutonymphs.

Average length and width of idiosoma: $467 / 357 \mu \mathrm{m}$ (in females); $367 / 278 \mu \mathrm{m}$ (in males).

Localities in Giresun. Alucra and Çamoluk.
Known distribution. Turkey (Urhan 2012).

Remark. Type materials of this species were collected from Giresun province.

\section{Zercon karadaghiensis Balan, 1992}

(Figures 3A-D)

Material examined. 25 우 and 23 ठิ $\widehat{0}$.

Average length and width of idiosoma: $446 / 327 \mu \mathrm{m}$ (in females); $353 / 237 \mu \mathrm{m}$ (in males).

Localities in Giresun. Bulancak.

Known distribution. Ukraine and Turkey (Balan 1992, Ujvári 2009, Urhan et al. 2012).

Description. Female.

Dorsal side (Figure 3A). 20 pairs of different setae present on podonotum's dorsal side: j-row with 6 pairs, z-row with 2 pairs, s-row with 6 pairs, r-row with 6 pairs. 2 pairs of different setae present on podonotum's ventral side: p-row with two pairs. On podonotum, all setae short, smooth and needle-like (except setae j1-2 and r1-6). Setae j1 densely barbed, j2 and $\mathrm{r} 1-6$ finely barbed. 22 pairs of different setae present on opisthonotum's dorsal side: J-row with 6 pairs, Z-row with 5 pairs, S-row with 4 pairs, R-row with 7 pairs. On opisthonotum, all setae smooth, finely barbed without hyaline ending or finely barbed with hyaline ending. Setae J1-2 and Z1-2 smooth and needle-like. Setae J3-6, Z3-4 and S3-4 long, finely barbed with hyaline endings. Seta J6 longest seta on opistonotum. On opistonotum setae J3-5 and Z3-4 reaching base of the following seta in the series. Setae S1-2 finely barbed with hyaline ending. Setae J5 and S2 reaching the margin of opistonotum but setae Z4 and S3-4 reaching beyond of opistonotum. Seta Z5 short but finely barbed with hyaline ending. Marginal $\mathrm{R}$ setae finely barbed without hyaline ending (except R7). Seta R7 smooth and needle-like, similar in appearance to setae $\mathrm{J} 1-2$. The distance between setae $\mathrm{J} 6$ and $\mathrm{Z5} 25-30 \mu \mathrm{m}$.

Pores (Fig. 3A). 3 different pores present on podonotum. Pores po1 under base of s1, po2 inside line connecting $\mathrm{j} 4$ and $\mathrm{s} 4$, po3 on line connecting $\mathrm{z} 1$ and $\mathrm{s} 5$, closer to s5. Podonotum 

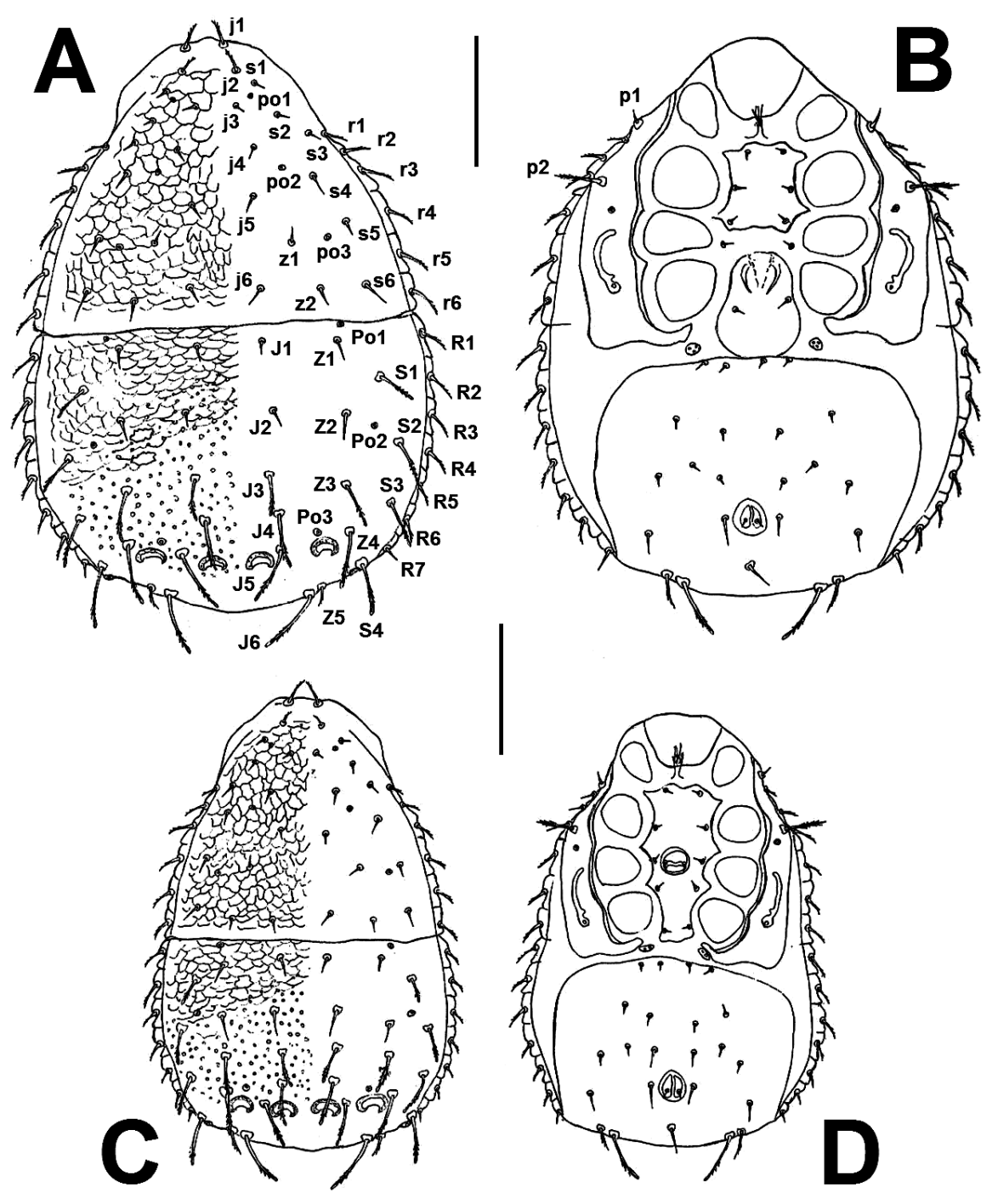

Figure 3. Zercon karadaghiensis. A) Dorsal view of female, B) Ventral view of female, C) Dorsal view of male, D) Ventral view of male $($ Scale bars $=100 \mu \mathrm{m})$.

covered by tile-like pattern. 4 different pores present on opisthonotum. Pores Po1 located above base of Z1, Po2 on line connecting Z2 and S2, Po3 outside the line connecting J5 and Z4, Po4 located close to the base of seta S4. Opisthonotal shield with a distinct reticulate pattern in the anterior region and spotted pattern in the posterior region. Dorsal cavities of general size and appearance, saddle-like, axes parallel to that of the body.

Ventral side (Fig. 3B). Ventral shields' shape, chaetotaxy and the shape of peritremes typical for genus Zercon. Setae p1 short, smooth and needlelike, seta p2 markedly elongated, finely plumose and feather-like. The shapes of peritremes bent, comma-like. Lateral ends of peritremal shield reach R1. Adgenital shields present (with three opening valves). Ventroanal shield with 9 pairs of setae. Anterior margin of ventroanal shield with 4 setae and postanal seta is single. All of them smooth and needle-like.

Lengths of opisthonotal setae and distances between setae within longitudinal rows of female and male specimens: see Table 1.

Male. Dorsal side (Fig. 3C), ventral side (Fig. 3D), shapes of setae on idiosoma, sculpture of 
podonotum and opisthonotum, size and appearance of dorsal cavities basically similar to that of female.

Remarks. Original description of this species was given by Balan (1992) from Ukraine. Ujvári (2009) recorded this species for the second times in the country and provided a detailed redescription.

Distinguishing characters of Z. karadaghiensis specimens known from Ukraine and Turkey are compared on the basis of the available literature (Table 2). The negligible different positions of pores may be a result of variation in Zerconidae species.

\section{Zercon mirabilis Urhan \& Öztaş, 2013}

Material examined. 216 우, 44 ठิึ, 150 deutonymphs and 83 protonymphs.

Average length and width of idiosoma: $466 / 354 \mu \mathrm{m}$ (in females); $378 / 272 \mu \mathrm{m}$ (in males).

Localities in Giresun. Şebinkarahisar and Doğankent.

Known distribution. Turkey (Urhan \& Öztaş 2013).

Remark. Type materials of this species were collected from Giresun province.

\section{Zercon ozkani Urhan \& Ayyıldız, 1994}

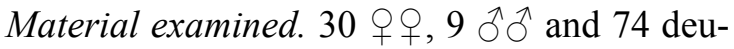
tonymphs.

Average length and width of idiosoma: $491 / 359 \mu \mathrm{m}$ (in females); 397/271 $\mu \mathrm{m}$ (in males).

Localities in Giresun. Bulancak, Şebinkarahisar and Doğankent.

\section{Known distribution. Turkey (Urhan \& Ayyıldız, 1994a).}

\section{Altitude preferences of zerconids}

Samplings was carried out from 0 to 2000 meters. No samples were collected between 600 800 and 1300-1500 meters because of a lack of suitable forestlands. The sampling localities in the research area were grouped according to 100 meter wide elevation ranges. Altitudinal distribution data of the detected zerconid specimens are listed in Table 3.

\section{Habitat preferences of zerconids}

According to the sampling localities in the research area, the following habitats were included: alder: Alnus sp., chestnut: Castanea sativa, common hazel: Corylus avellana, common

Table 1. Length intervals of opisthonotal setae and the distances between their bases in J-, Z- and S- rowsof Zercon karadaghiensis.

\begin{tabular}{|c|c|c|c|c|c|c|c|c|}
\hline Seta & $q 0$ & $\hat{\sigma} \sigma^{\lambda}$ & Seta & 우우 & $\partial^{\lambda}{ }^{\lambda}$ & Seta & 우우 & $\hat{\partial} 0^{\lambda}$ \\
\hline $\mathrm{J} 1$ & $10-14$ & $11-13$ & Z1 & 12-17 & 11-14 & S1 & 26-31 & $19-23$ \\
\hline$\uparrow$ & $51-61$ & $38-45$ & $\uparrow$ & $55-59$ & $40-43$ & $\uparrow$ & 51-61 & $36-40$ \\
\hline $\mathrm{J} 2$ & 14-18 & 14-17 & $\mathrm{Z} 2$ & $16-20$ & $11-16$ & S2 & $40-44$ & $29-34$ \\
\hline$\uparrow$ & $45-49$ & $30-34$ & $\uparrow$ & $50-56$ & $33-39$ & $\hat{\imath}$ & $51-54$ & $32-38$ \\
\hline $\mathrm{J} 3$ & $27-35$ & $24-30$ & Z3 & $38-46$ & $32-39$ & S3 & $49-52$ & $37-42$ \\
\hline$\uparrow$ & $32-42$ & $23-25$ & $\uparrow$ & $40-44$ & $26-33$ & $\hat{\imath}$ & 43-45 & $28-32$ \\
\hline J4 & $51-53$ & $39-41$ & $\mathrm{Z} 4$ & 54-59 & $48-52$ & S4 & $52-55$ & $45-47$ \\
\hline$\uparrow$ & $24-31$ & $16-19$ & $\uparrow$ & $38-45$ & $23-26$ & & & \\
\hline J5 & $54-56$ & $43-46$ & $\mathrm{Z5}$ & 13-23 & 13-17 & & & \\
\hline$\uparrow$ & $22-30$ & $24-28$ & & & & & & \\
\hline J6 & $62-66$ & 56-60 & & & & & & \\
\hline J6-J6 & $98-117$ & $91-96$ & & & & & & \\
\hline
\end{tabular}


Table 2. Distinguish characters between Ukrainian and Turkish specimens of Zercon karadaghiensis (measurements in micrometers, n: number of examined specimens).

\begin{tabular}{|c|c|c|c|}
\hline & Balan (1992) & Ujvári (2009) & Turkish specimens \\
\hline $\begin{array}{l}\text { Length and width inter- } \\
\text { vals of idiosoma }(ㅇ+9)\end{array}$ & $513-576 \times 410-428$ & $410 \times 393(n: 2)$ & $421-470 \times 314-339(\mathrm{n}: 25)$ \\
\hline $\begin{array}{l}\text { Length and width inter- } \\
\text { vals of idiosoma }\left(\hat{\sigma}^{\lambda} \hat{o}^{\lambda}\right)\end{array}$ & $416-450 \times 296-319$ & $360 \times 273(n: 2)$ & $339-367 \times 223-250(\mathrm{n}: 23)$ \\
\hline Setae in $r$ and $R$ series & $\begin{array}{l}\text { finely barbed without } \\
\text { hyaline ending }\end{array}$ & $\begin{array}{l}\text { finely barbed and flared } \\
\text { distally }\end{array}$ & $\begin{array}{l}\text { finely barbed without hyaline } \\
\text { ending }\end{array}$ \\
\hline Seta J3 $(\widehat{\jmath})$ & apically hyaline tip & not hyaline tip & apically hyaline tip \\
\hline Seta J5 & $\begin{array}{l}\text { not reach beyond of } \\
\text { opistonotum }\end{array}$ & $\begin{array}{l}\text { reach beyond of } \\
\text { opistonotum }\end{array}$ & $\begin{array}{l}\text { not reach beyond of } \\
\text { opistonotum }\end{array}$ \\
\hline Seta S1 & smooth & $\begin{array}{l}\text { finely barbed with hyaline } \\
\text { ending }\end{array}$ & $\begin{array}{l}\text { finely barbed with hyaline } \\
\text { ending }\end{array}$ \\
\hline Seta S2 & $\begin{array}{l}\text { reach beyond of } \\
\text { opistonotum }\end{array}$ & $\begin{array}{l}\text { not reach beyond of } \\
\text { opistonotum }\end{array}$ & $\begin{array}{l}\text { not reach beyond of } \\
\text { opistonotum }\end{array}$ \\
\hline Adgenital shields & $?$ & with 4 valves & with 3 valves \\
\hline
\end{tabular}

Table 3. Altitudinal ranges of zerconid mite species.

\begin{tabular}{|c|c|c|c|c|c|c|c|c|c|c|c|c|c|c|c|c|c|c|c|}
\hline $\begin{array}{l}\text { Altitude } \\
\text { (meters) }\end{array}$ & $\begin{array}{c}\frac{\pi}{3} \\
\vdots \\
\vdots \\
0 \\
0\end{array}$ & 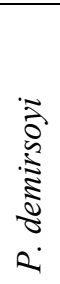 & 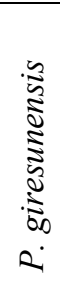 & 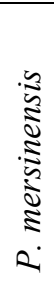 & 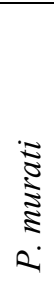 & 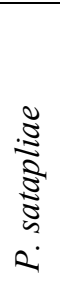 & 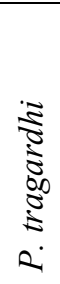 & 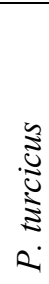 & 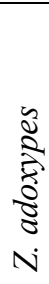 & 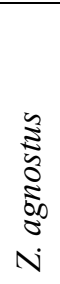 & 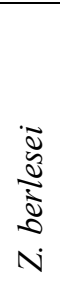 & 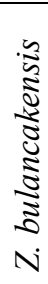 & 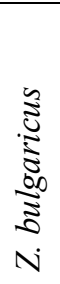 & 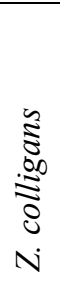 & 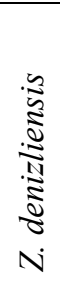 & N & 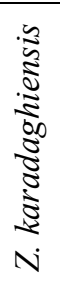 & 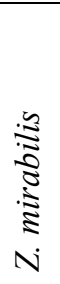 & $\begin{array}{c}\vec{\Xi} \\
\frac{\pi}{N} \\
0 \\
N\end{array}$ \\
\hline $0-100$ & + & + & & & + & + & + & & & & & + & & + & + & & & & \\
\hline $100-200$ & + & + & & & & & + & & & & & & & & + & & & & \\
\hline $200-300$ & & + & & & & & + & & & & & & & & & & & & \\
\hline $300-400$ & & + & & & & & + & & & & & & & & & & & & \\
\hline $400-500$ & + & + & + & & & & + & & & & + & + & & & + & & & + & + \\
\hline $500-600$ & & & & & & & + & & & & & & & & & & & & \\
\hline $600-700$ & & & & & & & & & & & & & & & & & & & \\
\hline $700-800$ & & & & & & & & & & & & & & & & & & & \\
\hline $800-900$ & + & + & & & & & & & & & + & & & & & & & & \\
\hline $900-1000$ & & & + & + & & & + & & & & & & & & & & & + & \\
\hline $1000-1100$ & & + & & + & & + & + & + & + & & + & + & + & & & & & + & + \\
\hline $1100-1200$ & & & & & & & & & & & & + & & & & & & + & + \\
\hline $1200-1300$ & & & + & + & & & & & & & & + & & & & & & + & \\
\hline $1300-1400$ & & & & & & & & & & & & & & & & & & & \\
\hline $1400-1500$ & & & & & & & & & & & & & & & & & & & \\
\hline $1500-1600$ & & & & & & & & & & + & & & & + & & + & & & \\
\hline $1600-1700$ & & & & & & & + & + & & + & & + & & + & & + & + & & \\
\hline $1700-1800$ & & & & & & & + & + & & & & + & & & & & + & & + \\
\hline $1800-1900$ & & & & & & & & + & & & & + & & + & & + & + & & \\
\hline $1900-2000$ & & & & & & & & & & & & & & + & & + & & & \\
\hline
\end{tabular}


Table 4. Habitat preferences of zerconid mite species.

\begin{tabular}{|c|c|c|c|c|c|c|c|c|c|c|c|c|c|c|c|c|c|c|}
\hline & 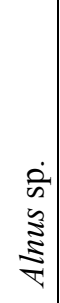 & 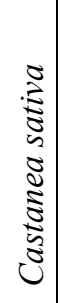 & 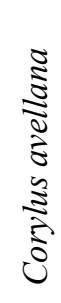 & 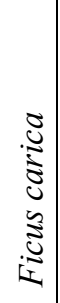 & 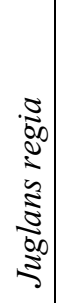 & 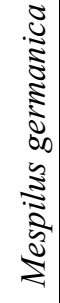 & $\sum_{\substack{\infty \\
\tilde{z}}}^{\infty}$ & 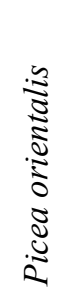 & 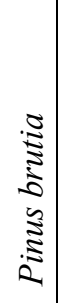 & 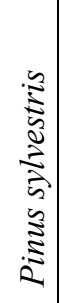 & 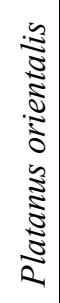 & 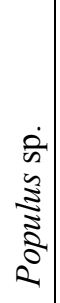 & 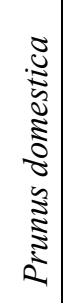 & $\begin{array}{c}\vdots \\
\vdots \\
\vdots \\
\vdots\end{array}$ & 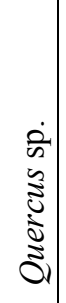 & 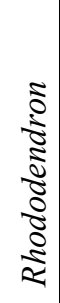 & 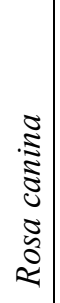 & 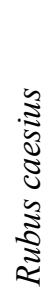 \\
\hline P. buraki & + & & + & & & + & + & & & & + & + & & + & + & & & + \\
\hline P. demirsoyi & + & & + & + & & & + & & + & + & & + & & + & + & + & & + \\
\hline P. giresunensis & & & & & & & & & & + & & + & + & & & & & \\
\hline P. mersinensis & + & & & & & & + & & & + & & + & & & & + & & \\
\hline P. murati & + & & + & & & & & & & & & & & & & & & \\
\hline P. satapliae & + & & + & & & & + & & + & + & & & & & & + & & \\
\hline P. tragardhi & + & + & + & & + & + & + & & + & + & + & + & & + & + & + & & + \\
\hline P. turcicus & + & & & & & & + & + & & + & & & & & & + & & \\
\hline Z. adoxypes & & & & & & & + & & & + & & & & & & + & & \\
\hline Z. agnostus & & & & & & + & & & & + & & & & & + & & & \\
\hline Z. berlesei & & & & & & & + & & & & & & & & & & & \\
\hline Z. bulancakensis & & & + & & + & & + & + & + & + & & & + & & + & + & & \\
\hline Z. bulgaricus & + & & & & & & + & & & + & & & & & & & & \\
\hline Z. colligans & & & & & & + & + & & & + & & + & & & + & & & \\
\hline Z. denizliensis & + & & + & & & + & & & & & & & & & + & & & + \\
\hline Z. imperfectsetosus & & & & & & + & + & & & & & + & & & + & & + & \\
\hline Z. karadaghiensis & & & & & & & + & + & & + & & & & & & & & \\
\hline Z. mirabilis & & & & & & & + & & & + & & + & & & + & + & & \\
\hline Z. ozkani & & & & & & & + & & & + & & + & & & + & & & \\
\hline
\end{tabular}

fig: Ficus carica, persian walnut: Juglans regia, common medlar: Mespilus germanica, moss, oriental spruce: Picea orientalis, Turkish pine: Pinus brutia, scots pine: Pinus sylvestris, oriental plane: Platanus orientalis, poplar: Populus sp., plum: Prunus domestica, cherry laurel: Prunus laurocerasus, oak: Quercus sp., yellow azalea: Rhododendron luteum, dog-rose: Rosa canina and European dewberry: Rubus caesius. The habitats of the different zerconid species are given in Table 4.

\section{DISCUSSION}

According to Table 3, the specimens of $P$. murati and $Z$. denizliensis occur only at lower altitudes (0-500 meters). In contrast, $Z$. adoxypes, $Z$. imferfectsetosus and Z. karadaghiensis occur only at higher mountain zones (over 1500 meters). $P$. tragardhi, Z. bulancakensis and Z. colligans show a wide range of occurrances from sea level up to high mountain zone. The remaining species have no clear preference in terms of altitudinal ranges.
According to Table 4, specimens of P. Tragardhi show no preferences towards the different forest types occurring in 14 different habitats. $P$. murati however, shows up in only two habitat types, under alder and common hazel.

In terms of species richness, under alder 7 species occured and in moss pads 6 species belonging to Prozercon were determined. Under chestnut, oriental spruce and plum only one species of Prozercon is recorded. However, under dog-rose no species of Prozercon is observed.

From the species of the genus Zercon, Z. bulancakensis is the most widespread occurring in 9 different habitats. This shows that $Z$. bulancakensis has a wider tolerance than the other Zercon species in the Giresun province. In contrast, $Z$. berlesei occurs only in one habitat type (in moss pads). In terms of species richness, in moss pads 9 species, under scots pine 8 species and under oak 7 species of the genus Zercon were recorded. Under chestnut no Zercon species were observed. 
The unique zoogeographical position of Turkey between Asia, Europe and North Africa, in the western Palearctic region provides a rich biological diversity in terms of both floral and faunal elements. Zerconid mites are closely related to litter types and plant communities which are specific to a particular area, this may allow spreading endemic zerconid species associated with these special floral elements. The type locality of 58 zerconid species are in Turkey, of these, only Prozercon yavuzi was recorded out of the country; from Greece (Ujvári 2008, 2011c).

As this vast country is still understudied, with local faunistic investigations (especially in the Black Sea and Mediterranean regions) further new species and new records of zerconids in Turkey are anticipated.

Acknowledgments - This study was financially supported by the Pamukkale University Scientific Research Projects (PAUBAP), project number: 2010FBE069. Also we would like to thank Murat Öztaş, who collected the soil samples from Giresun province, and Assoc. Prof. Dr. Ali Nafiz Ekiz (Uşak University, Turkey) for linguistic correction of the manuscript.

\section{REFERENCES}

BALAN, P.G. (1992): New mite species of the genus Zercon (Acari, Mesostigmata) from the Crimea (In Russian). Vestnik Zoologii, 1992(4): 49-55.

BŁASZAK, C. (1979): Systematic studies on the family Zerconidae, IV. Asian Zerconidae (Acari, Mesostigmata). Acta Zoologica Cracoviensia, 24(1): 3112.

KARACA, M. (2015): Trakya bölgesi (Türkiye) zerkonid akarları (Acari, Mesostigmata, Zerconidae) üzerine sistematik araştırmalar. Institute of Sciences, Pamukkale University, Denizli, Ph. D. Thesis, 282 pp.

KARACA, M. \& URHAN, R. (2014): Contributions with new records to zerconid mite fauna of Turkey (Acari: Zerconidae). Turkish Bulletin of Entomo$\log y, 4(3)$ : 147-155.

KARACA, M. \& URHAN, R. (2015a): A new record of zerconid mites (Acari, Mesostigmata, Zerconidae) from the Thrace region of Turkey. Turkish Journal of Zoology, 39(1): 188-190. doi: 10.3906/zoo-1312-39
KARACA, M. \& URHAN, R. (2015b): Two new records of the genus Prozercon Sellnick, 1943 (Acari: Zerconidae) from Turkey. Turkish Journal of Zoology, 39(5): 949-955. doi: 10.3906/zoo-1410-21

KRANTZ, K. W. (1978): A manual of acarology. Second edition, Oregon State University, Corvallis, Oregon, 509 pp.

MA, L.M., Ho, C.C. \& WANG, S.C. (2011): One new species of Zerconidae an done new recordes species of Blattisocidae from Taiwan (Acari: Mesostigmata). Formosan Entomologist, 31: 239-247.

MARTiKAinen, E. \& Huhta, V. (1990): Interactions between namatodes and predatory mites in raw humus soil: a microcosm experiment. Revue d'Ecologie et de Biologie du Sol, 27(1): 13-20.

MAŠÁN, P. \& FEND’A, P. (2004): Zerconid mites of Slovakia (Acari, Mesostigmata, Zerconidae). Slovak Academy of Sciences, Institute of Zoology, Bratislava, $238 \mathrm{pp}$.

SEllNICK, M. (1958): Die familie Zerconidae Berlese. Acta Zoologica Academiae Scientiarum Hungaricae, 3: 313-368.

ShereEF, G.M., AFIFI, M.Z. \& El Bishlawy, S.H.O. (1984): Description, life cycle and feeding habitats of Zercon adalicus n. sp. (Acari, Gamasida, Zerconidae). Bulletin of Faculty of Agriculture, Cairo University, 35: 1765-1774.

SIKORA, B. (2014): Mites of the family Zerconidae (Acari: Mesostigmata) of the Nearctic region. Annales Zoologici, 64 (2): 131-250 doi: $10.3161 / 000345414 X 682463$

UJVÁRI, ZS. (2008): Zerconid mites (Acari: Mesostigmata: Zerconidae) from Crete, Greece, with description of two new species. Opuscula Zoologica Budapest, 39: 99-108.

UJVÁRI, Zs. (2009): New and rare zerconid mites (Acari: Mesostigmata: Zerconidae) from the Crimean Peninsula, Ukraine. Opuscula Zoologica Budapest, 40(2): 75-86.

UJVÁRI, Zs. (2010): First records of zerconid mites (Acari: Mesostigmata: Zerconidae) from Albania, with description of three new species. Opuscula Zoologica Budapest, 41(1): 57-75.

UJVÁRI, Zs. (2011a): First records of Zerconidae (Acari: Mesostigmata) south of the tropic of Cancer, Mexico, with description of five new species. International Journal of Acarology, 37 (3): 201215. doi: 10.1080/01647954.2010.502907 
UJVÁRI, Zs. (2011b): New zerconid mites (Acari: Mesostigmata: Zerconidae) from Taiwan. Zoological Studies, 50 (1): 87-102.

UJVÁRI, Zs. (2011c): Six new species of Prozercon Sellnick, 1943 (Acari, Mesostigmata, Zerconidae) from Greece, with remarks on the genus. Zootaxa, 2785: 1-31.

UJVÁRI, Zs. (2012): Draconizercon punctatus gen. et sp. nov., a peculiar zerconid mite (Acari: Mesostigmata: Zerconidae) from Taiwan. Opuscula Zoologica Budapest, 43(1): 79-87.

URHAN, R. (1998): Some new species of the family Zerconidae (Acari, Mesostigmata) from Turkey. Journal of Natural History, 32: 533-543. doi: $10.1080 / 00222939800770291$

URHAN, R. (2008): Contributions to the genus Prozercon Sellnick, 1943 (Acari: Zerconidae) from Turkey, with the description of two new species and a key to species. Zoology in the Middle East, 45: 97-104. doi: 10.1080/09397140.2008.10638312

URHAN, R. (2010): Prozercon celali sp. nov. of soil mites (Acari: Zerconidae) from Turkey. Annales Zoologici, 60(1): 133-137. doi: $10.3161 / 000345410 \times 499614$

URHAN, R. (2011): Two new species of zerconid mites (Acari, Mesostigmata) from Honaz Mountain National Park (Turkey). Turkish Journal of Zoology, 35(2): 163-174.

URHAN, R. (2012): Two new species of Zercon C. L. Koch, 1836 from Turkey. Zoology in the Middle East, 56: 125-132.

Doi: $\underline{10.1080 / 09397140.2012 .10648947}$

URHAN, R. (2013): Two new species of zerconid mites (Acari: Zerconidae) from Giresun Province (Turkey). Turkish Journal of Zoology, 37: 172-178.

URHAN, R. \& AYYILDIZ, N. (1992): Türkiye faunas1 için yeni bir Prozercon Sellnick, 1943 (Acari, Mesostigmata, Zerconidae) türü. Turkish Journal of Zoology, 17: 83-89.

URHAN, R. \& AYYILDIZ, N. (1994a): Two new species of the genus Zercon Koch (Acari, Zerconidae) from
Turkey. International Journal of Acarology, 19(4): 335-339. doi: $10.1080 / 01647959308683988$

URHAN, R. \& AYYILDIZ, N. (1994b): Türkiye faunası için yeni Zercon C. L. Koch, 1836 (Acari, Mesostigmata, Zerconidae) türleri. Turkish Journal of Zoology, 18(1): 53-60.

URHAN, R. \& AYYILDIZ, N. (1996a): Three new species of Prozercon Sellnick (Acari, Mesostigmata, Zerconidae) from Turkey. Acarologia, 37(4): 259-267.

URHAN, R. \& AYYILDIZ, N. (1996b): Zercon bulgaricus Balogh, 1961, a new species for the fauna of Turkey (Acari, Mesostigmata, Zerconidae). Turkish Journal of Zoology, 20(4): 437-440.

URHAN, R. \& AYYILDIZ, N. (1996c): Türkiye faunası için dört yeni Zercon C. L. Koch, 1836 (Acari, Mesostigmata, Zerconidae) türü. Turkish Journal of Zoology, 20: 293-302.

URHAN, R. \& AYYILDIZ, N. (1996d): Two new species of the genus Prozercon Sellnick from Turkey (Acari: Zerconidae). Genus, 7(3): 569-580.

URHAN, R. \& AYYILDIZ, N. (1996e): Artvin ili zerkonidleri (Acari, Mesostigmata, Zerconidae) üzerine sistematik araştırmalar-I (In Turkish). Turkish Journal of Zoology, 20: 341-347.

URHAN, R. \& ÖZTAŞ, M. (2013): A new species of mite from Turkey: Zercon mirabilis sp. n. (Acari: Zerconidae). Zoology in the Middle East, 59(1): 84-88. doi: 10.1080/09397140.2013.795072

Urhan, R. A Ayyildiz, N., ToluK, A., KoçOĞLU, E. \& TAŞDEMIR, A. (2007): Zercon agnostus Błaszak, 1979 (Acari: Zerconidae) üzerine bir çalışma (In Turkish). Journal of Arts and Sciences, FenEdebiyat Fakültesi, Çankaya Üniversitesi, Sayı 7: 171-179.

URHAN, R., ÖZTAŞ, M. \& KARACA, M. (2012): Giresun'dan Türkiye faunası için yeni bir zerkonid akar (Acari, Zerconidae) türü: Zercon karadaghiensis (In Turkish). 21. Ulusal Biyoloji Kongresi, 3-7 September 2012,Ege University, İzmir, Turkey, p. 1100-1101. 